\title{
Using ALS raster data in forest planning
}

\author{
Timo Pukkala ${ }^{1}$
}

Received: 25 January 2019/Accepted: 25 February 2019/Published online: 15 April 2019

(c) The Author(s) 2019

\begin{abstract}
Raster type of forest inventory data with site and growing stock variables interpreted for small squareshaped grid cells are increasingly available for forest planning. In Finland, there are two sources of this type of lattice data: the multisource national forest inventory and the inventory that is based on airborne laser scanning (ALS). In both cases, stand variables are interpreted for $16 \mathrm{~m} \times 16 \mathrm{~m}$ cells. Both data sources cover all private forests of Finland and are freely available for forest planning. This study analyzed different ways to use the ALS raster data in forest planning. The analyses were conducted for a grid of $375 \times 375$ cells $(140,625$ cells, of which 97,893 were productive forest). The basic alternatives were to use the cells as calculation units throughout the planning process, or aggregate the cells into segments before planning calculations. The use of cells made it necessary to use spatial optimization to aggregate cuttings and other treatments into blocks that were large enough for the practical implementation of the plan. In addition, allowing premature cuttings in a part of the cells was a prerequisite for compact treatment areas. The use of segments led to 5-9\% higher growth predictions than calculations based on cells. In addition, the areas of the most common fertility classes were overestimated and the areas of rare site classes were
\end{abstract}

Project funding: No funding received.

The online version is available at http://www.springerlink.com

Corresponding editor: Yu Lei.

Timo Pukkala

timo.pukkala@uef.fi

1 University of Eastern Finland, Yliopistokatu 7, 80100 Joensuu, Finland underestimated when segments were used. The shape of the treatment blocks was more irregular in cell-based planning. Using cells as calculation units instead of segments led to 20 times longer computing time of the whole planning process than the use of segments when the number of grid cells was approximately 100,000 .

Keywords Raster data $\cdot$ ALS-based inventory $\cdot$ Spatial optimization - Segmentation - Simulated annealing · Cellular automata

\section{Introduction}

Forest inventories in Finland and other countries rely increasingly on airborne laser scanning (ALS) data (Mozgeris 2009; Shan et al. 2009; Maltamo et al. 2014). The area-based interpretation approach of ALS data may interpret stand characteristics for any area, for instance existing stands, numerically derived segments, or grid cells (Vauhkonen et al. 2014). In Finnish ALS-based forest inventory, site and stand variables are systematically calculated for both existing stands and grid cells of $16 \mathrm{~m} \times 16 \mathrm{~m}$ (www.metsakeskus.fi).

From the interpretation point of view, the ideal size of the interpretation unit is the same as the area of the field plots that are used in area-based interpretation (Pascual et al. 2018). Therefore, stand attributes interpreted for grid cells may be regarded as better estimates than attributes interpreted for larger areas. Another problem of using existing stands as interpretation units is that they are often subjectively demarcated and sometimes obsolete. Fixed stand boundaries decided before the planning calculations are constraints, which decrease the possibilities of forest 
planning to optimize forest management (Heinonen et al. 2007).

Modern landscape level forest planning typically consists of two steps (Falcão and Borges 2002; Pukkala 2004; Hirvelä et al. 2017). First, alternative treatment schedules are simulated for the calculation units, which can be inventory plots, grid cells, segments, stands, or strata. Then, combinatorial optimization is used to find such a combination of the simulated treatment schedules, which maximizes the objective function of the forest landowner (e.g., net present value) while satisfying the possible constraints (e.g., non-decreasing timber drain, sufficient area of old-forest habitat). Linear programming, goal programming and various metaheuristics can be used for combinatorial optimization (Kangas and Pukkala 1992; Borges et al. 2002; Bettinger et al. 2002; Shan et al. 2009; Lappi and Lempinen 2014).

In Finland, ALS-based stand attribute data are currently freely available for anyone, for both stands and grid cells. These data sources provide very good input data for forest planning since the data are detailed and spatially continuous. The precision of ALS based forest inventory is the same as or better than achieved in visual relascope inventory (Næsset 2002; Packalén 2009; Vauhkonen et al. 2014). If grid data are used, planning is not constrained by existing and fixed stand boundaries. Theoretically, this offers possibilities to improve the quality of planning and increase the efficiency of forest production (Heinonen et al. 2007)

On the other hand, some problems arise when grid data are used in forest planning. First, the computational burden greatly increases if grid cells are used as calculation units throughout the planning process. Second, the harvest blocks and other treatment units, derived in planning calculations, may be too small, irregular and scattered for the implementation of the plan.

An obvious solution to the first problem is to aggregate the cells into homogeneous segments before planning calculations (Mozgeris 2009; Dechesne et al. 2017; Pascual et al. 2018). The second problem can be alleviated by using spatial optimization to aggregate treatments (Heinonen et al. 2018). Pre-planning segmentation is also a partial solution to the second problem (Pascual et al. 2018). However, if the segments produced before planning calculations (i.e., before simulation and optimization) are small, it is possible to increase the aggregation of cuttings and other treatments by using spatial optimization. In this case, aggregation is started with pre-planning segmentation and continued by using spatial optimization.

This study explored the effects these methodologies (pre-planning segmentation and spatial optimization) on the time consumption of the planning process, estimated forest attributes, and similarity of prescriptions. The study aimed at producing useful information for the use of the current sources of grid data in forest management planning. In addition to the ALS-based forest inventory data, the results of the multi-source forest inventory of Finland are also available for $16 \mathrm{~m} \times 16 \mathrm{~m}$ raster cells (Tomppo et al. 2008). Also this source of raster data can be used in forest planning (Mäkisara et al. 2016).

Three alternatives to use raster data in forest planning were analyzed: (1) using grid cells as calculation units and spatial optimization to aggregate treatments (this alternative is referred to as post-simulation aggregation); (2) aggregating cells into large enough segments to serve as treatment units (pre-simulation aggregation); and (3) using segmentation to create small segments, and then using spatial optimization to further aggregate treatments (preand post-simulation aggregation). These three options differ in the need for spatial optimization: spatial optimization is necessary when cells are used as simulation units, useful with small segments, and not necessary with large segments.

It is obvious that simulation and optimization are the fastest when large segments are used as simulation units. On the other hand, the use of large segments omits the within-stand spatial variation in site and growing stock characteristics, which may cause bias. It may be hypothesized that pre-planning aggregation leads to overestimated growth prediction due to the concave relationship between stand density and increment (Pukkala 1990). This may lead to overestimated net present value and wood production.

The segments formed by aggregating grid cells most probably have within-stand variation also in site characteristics. The most important site characteristics in Finland are categorical variables such as fertility class and soil type (for instance mineral soil vs. peat). If the most common category among the cells that constitute the segment is given to the whole segment, it can be hypothesized that the areas of common site categories become overestimated and the areas of rare site types are underestimated if calculation is based on segments.

\section{Materials and methods}

\section{Materials}

The ALS-based forest inventory data are organized into sets of $375 \times 375$ cells of $16 \mathrm{~m} \times 16 \mathrm{~m}$ in size (3600 ha). Ordinary site and stand characteristics are available for each cell. The site characteristics include land use category (productive forest, stunted forest, agricultural land, etc.), soil group (mineral soil, spruce mire, pine bog, and open bog), and fertility class (mesotrophic herb-rich, herb-rich, mesic, sub-xeric, xeric, and barren heath). The growing 
stock characteristics include all variables required in Finnish forest planning systems, namely stand basal area, number of trees per hectare, stand age, mean tree diameter and mean tree height. These attributes are available for the total growing stock and separately for pine, spruce and broadleaves.

One set of ALS data from eastern Finland was downloaded from www.metsaan.fi/paikkatietoaineistot. The whole set of $375 \times 375$ cells (3600 ha) was used in the planning calculations of this study (the $x$ and $y$ coordinates of the lower left corner of the study area were 650,000 and $6,924,000 \mathrm{~m}$, respectively, in the GRS 1980 Transverse Mercator system). In addition, a sub-sample of $236 \times 149$ cells (900 ha) was selected to have two different sizes of ALS grids. The cells and the variables available for the cells were either used directly as simulation units, or they were passed to a segmentation software to aggregate the cells into larger simulation units. In both cases, cells which were not classified as productive forest land were discarded. These cells mainly represented lakes, agricultural fields, roads, stunted forest (mean annual volume increment $0.1-1 \mathrm{~m}^{3} \mathrm{ha}^{-1}$ ) and wasteland (forestry land with mean annual volume increment less than $0.1 \mathrm{~m}^{3} \mathrm{ha}^{-1}$ ). The area of productive forest was 2500 ha in the grid of $375 \times 375$ cells and 603 ha in the grid of $236 \times 149$ cells. In the results section, numerical results are reported for the whole area but maps are shown only for the sub-area (for better visibility).

\section{Segmentation}

The study employed existing methodologies developed for segmentation, simulation and optimization. Since all these methods have been described in detail is earlier literature, only brief descriptions are given here.

The segments were formed by the cellular automaton described in Pukkala (2019). The cell features used in segmentation were land use category, soil group, fertility class, mean height, mean diameter and stand basal area. Stand attributes of the total growing stock were used (not species-specific values). Land use category was used as a mask to filter-out cells that did not represent productive forest.

The cellular automaton (CA) first divided the area into square-shaped initial segments of equal size. Then, each cell of the grid was joined to one of its adjacent segments for several iterations, based on the following criteria: (1) length of common border between the cell and the segment, (2) area of the segment, and (3) similarity of stand attributes in the cell and the segment (Fig. 1). A cell could have a maximum of four adjacent segments, depending on the segment number of the cell to the east, west, north and south. Segmentation aimed at decreasing within-segment variation in stand attributes while maximizing betweensegment variation. At the same time, the purpose was to create compact segments and avoid forming very small segments. The method is described in detail in a recent article (Pukkala 2019).

Segmentations with two different segment sizes were accomplished by altering the initial size of the segments and the parameters of the CA. These two segmentations are referred to as small and large segments. The main parameters that were used to control the size of the segments was the area of initial segments $(0.5$ and 3 ha, respectively, when the aim was to create small and large segments), and the weight of segment area when deciding the segment to which a cells was joined.

\section{Calculation of stand attributes for segments}

After creating the segments, their stand attributes were derived from the corresponding attributes of the cells that constituted the segment. Categorical variables (soil group and fertility class) were obtained as the mode of the cell values (the most common value of the cells was given to whole segment). The stand basal area of the segment was calculated as the mean of the cells values. Mean diameter and mean height were calculated as basal-area-weighted means of the cell values.

Although segmentation was based on the attributes of the total growing stock, the segment values of basal area, mean dimeter and mean height were calculated separately

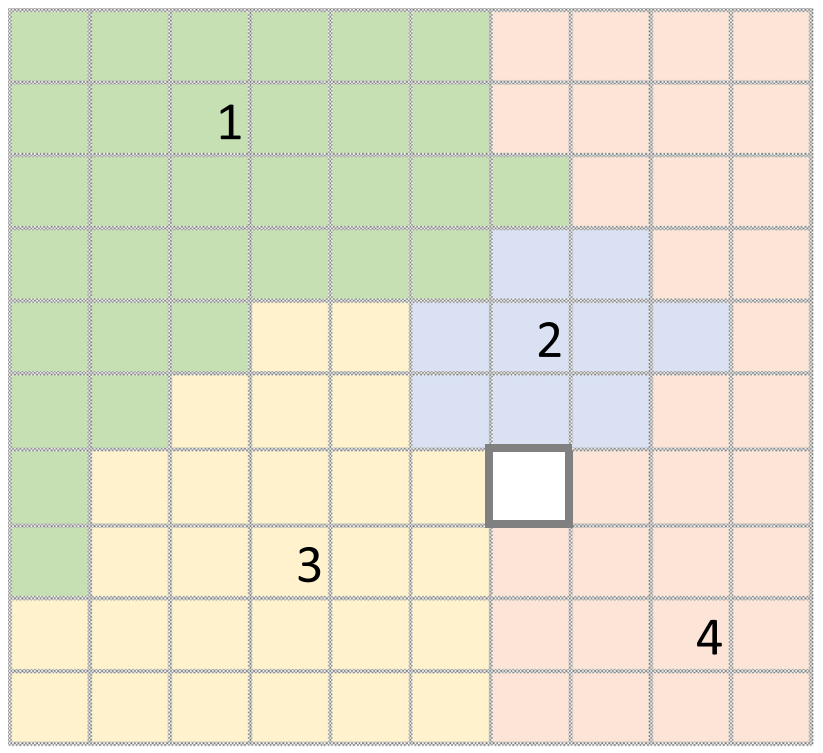

Fig. 1 In the cellular automaton used for segmentation, each segment is joined to one of its adjacent segments for several iterations. The white cell is joined to segment 2,3 or 4 , depending on the weight of the area of the segment, length of common border between the cell and the segment, and similarity of stand attributes in the cell and segment 
for Scots pine (Pinus sylvestris L.), Norway spruce (Picea abies Karst (L.) H. Karst) and broadleaved species. The broadleaf species was assumed to be silver birch (Betula pendula Roth).

The area of the segment was equal to the area of cells that belonged to the segment. The stand attributes obtained in this way were imported to a forest planning system. When cells were used as simulation units, the values of the above-listed stand attributes were obtained directly from the ALS data.

Adjacency information, required in spatial optimization, was calculated in GIS. It consisted of the length of common boundary between adjacent cells or segments. In the case of segments, the "raster to polygon" tool of the GIS software (ArcMap) was used to straighten segment boundaries (Fig. 2). The length of the common boundary between adjacent segments was calculated from the obtained polygons.

\section{Simulation}

The site and stand variables, as well as the adjacency information, were imported to the Monsu forest planning software (Pukkala 2004). Monsu was first used to calculate forest-level variables for different datasets to find out whether segmentation leads to biased estimates. Then, the simulation tool of Monsu was used to simulate alternative treatment schedules for each simulation unit (cells or segments) for a 10-year period. The treatments of the schedule were simulated in the middle of the 10-year period. All schedules represented even-aged management. The possible cutting types were thinning, clear-felling, seed tree cut, or removing the upper canopy layer from a two-storied stand. Pre-commercial thinnings were simulated for young seedling and sampling stands. After clear-felling, site preparation and artificial regeneration were simulated for the same 10-year period.

Simulation of cutting was based on instructions for the minimum mean diameter at clear-felling and minimum stand basal area at thinning ( ̈̈ijälä et al. 2014). Alternative schedules were obtained by postponing the cutting from the earliest moment dictated by the thinning basal area and clear felling diameter. If the removal of a thinning treatment was less than $30 \mathrm{~m}^{3} \mathrm{ha}^{-1}$, the schedule was rejected, i.e., thinning was not simulated. All simulation units had also a treatment schedule in which there was no cutting. The average number of different schedules was only around two per simulation unit (segment or cell) since there was only one 10-year period and many segments had only one realistic management option for the coming 10-year period (usually, letting the stand grow without any treatment).

It was anticipated that the use of cells might lead to irregular treatment units with uncut cells within harvest blocks. This is because there may be sparse cells within thinning areas and cells of smaller trees within clear-felling areas. One reason for this outcome is that thinning alternatives may not be simulated for sparse cells, and clearfelling alternatives may not be simulated for cells where the trees are smaller than the clear-felling diameter. Therefore, a second set of simulations was conducted for cells so that the basal area required for thinning and the mean diameter required for final felling were both multiplied by 0.8 . In addition, the minimum thinning removal was reduced from 30 to $5 \mathrm{~m}^{3} \mathrm{ha}^{-1}$. These changes made it possible to cut sparsely populated cells simultaneously with the other cells of a thinning block, or clear-cut a cell of smaller trees simultaneously with the cells of a clearfelling block. In the cell-based simulation for the whole area, this adjusted parametrization was used as the only alternative.

\section{Optimization}

Simulated annealing programmed in Monsu (Pukkala and Kurttila 2005) was used for combinatorial optimization. Simulated annealing (SA) is a cooling method resembling threshold accepting and great deluge (Bettinger et al. 2002). First, an initial solution was produced by randomly selecting a treatment schedule for each simulation unit from those simulated beforehand. Then, a candidate solution was produced by selecting a random simulation unit and then a random treatment schedule of the selected unit (from the schedules simulated beforehand). If the candidate solution obtained in this way produced a higher objective function value than the current solution, it became the new current solution. Otherwise, the candidate solution was either accepted or rejected, depending on the current "temperature" of the SA process. A certain number of candidate solutions were produced and evaluated in this way. Then, the temperature was decreased, which reduced the probability of accepting inferior solutions. After this, a certain number of candidate solutions was evaluated again in the new temperature. The number of evaluated candidates was increased by $5 \%$ when the temperature was decreased, to intensify search when the process cooled. The search was terminated when the temperature fell below a predefined freezing temperature.

SA was parametrized following the guidelines of Pukkala and Heinonen (2006):

- Initial temperature $=0.1 / n$ ( $n$ is the number of simulation units)

- Freezing temperature $=($ Initial temperature $) / 20$

- Number of candidates evaluated at initial temperature $=n$

- $\quad$ Iteration multiplier $=1.05$ 

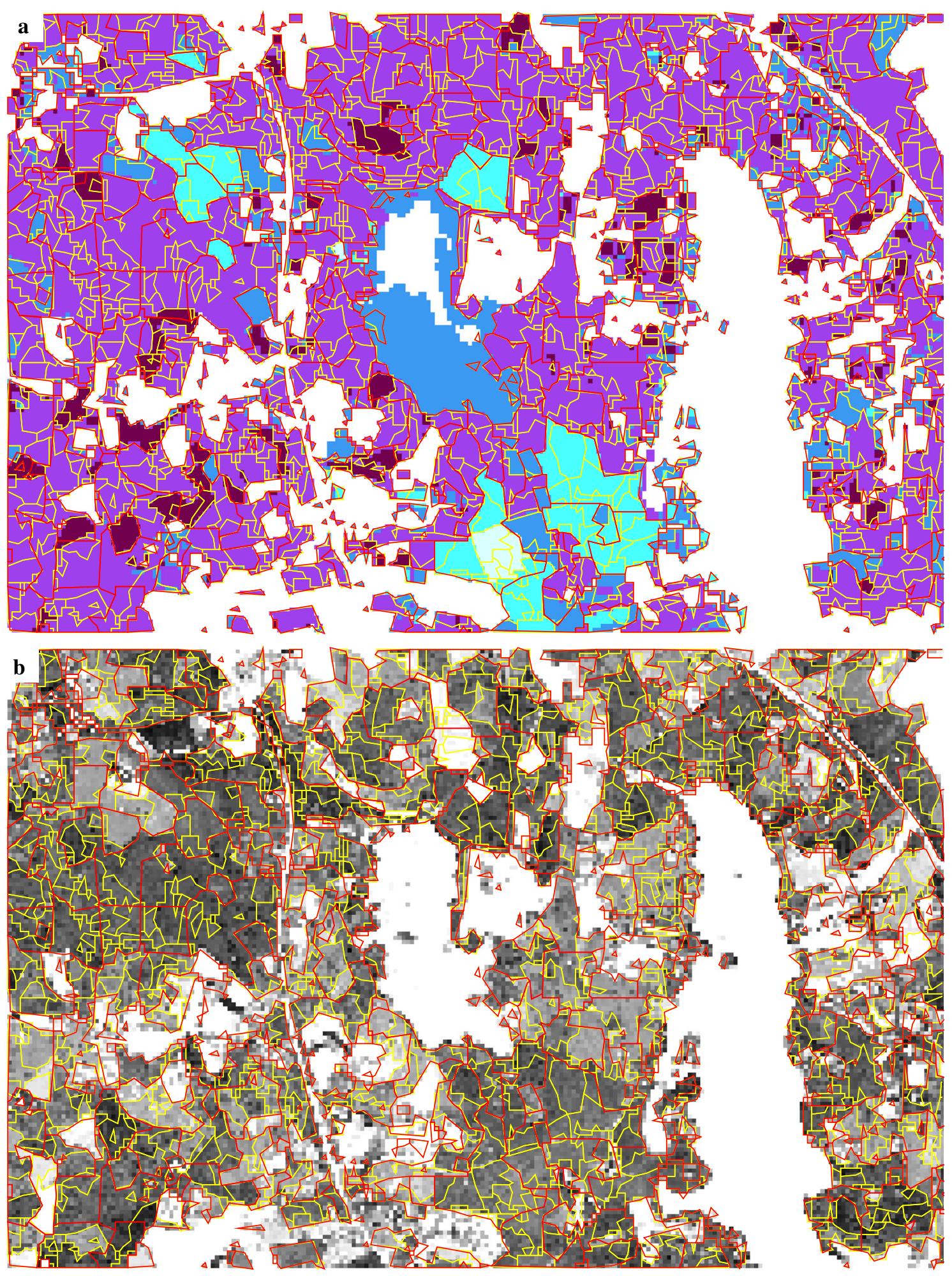

Fig. 2 Segment boundaries (small segments drawn with yellow lines and large segments with red lines) with fertility class (a) and mean diameter (b). Darker tone implies higher fertility. The most common fertility class (purple) is herb-rich. In the lower map, dark tone implies high mean diameter. The highest mean diameter (black color) is $30 \mathrm{~cm}$ 
- $\quad$ Cooling multiplier $=0.9$

The last two parameters were used as follows: after evaluating a certain number of candidate solutions, the temperature was multiplied by 0.9 and the number of evaluated candidates per temperature was multiplied by 1.05 .

\section{Objective function}

In all optimizations, the target value for the total 10 -year harvest was set in such a way that the initial growing stock volume of the forest was maintained. The target harvest was $35,000 \mathrm{~m}^{3}$ for the subarea of 900 ha and $140,000 \mathrm{~m}^{3}$ for the total area of 3600 ha. The net present value calculated with a $3 \%$ discount rate was maximized with this harvesting target. Calculation of net present value took into account the predicted NPV of the remaining growing stock at the end of the 10-year period (Pukkala 2015). Both non-spatial and spatial versions of the planning problems were solved. The spatial problems included additional objective variables aiming at aggregating all cuttings and separately aggregating final fellings.

Technically, the problems were formulated in the utility theoretic way as follows (Pukkala and Kangas 1993):

$\max U=\sum_{k=1}^{K} w_{k} u_{k}\left(q_{k}\right)$

subject to:

$q_{k}=Q_{k}(\mathbf{x}) \quad k=1, \ldots, K$

$\sum_{i=1}^{n_{j}} x_{i j}=1 \quad j=1, \ldots, n$

$x_{i j}=\{0,1\}$

where $K$ is the number of objective variables, $w_{k}$ is the weight, $u_{k}$ is the sub-utility function, and $q_{k}$ is the quantity of objective variable $k, n$ is the number of simulation units, $n_{j}$ is the number of treatment alternatives simulated for unit $j, Q_{k}()$ is the procedure that calculates the value of objective variable $k$ for a candidate solution, and $\mathbf{x}$ is a vector holding information on the treatment schedules that are included in the solution. It is a vector of $0-1$ variables, where 1 indicates that the schedule belongs to the solution.

The objective functions of the non-spatial and spatial problems were as follows:Non-spatial problem:

$U=w_{1} u_{1}(N P V)+w_{2} u_{2}(H V)$

Spatial problem:

$\begin{aligned} U= & w_{1} u_{1}(N P V)+w_{2} u_{2}(H V)+w_{3} u_{3}(C C)+w_{4} u_{4}(C n C) \\ & +w_{5} u_{5}(F F)+w_{6} u_{6}(F n F)\end{aligned}$ where $N P V$ is net present value calculated with a $3 \%$ discount rate $(€), H V$ is harvested volume $\left(\mathrm{m}^{3}\right), C C$ is the length of cut-cut boundary (boundary between two adjacent simulation units that are both cut during the 10-year period), $C n C$ is the length of cut-non-cut boundary, $F F$ is the length of the boundary between such adjacent simulation units that are both treated with final felling (clearfelling or seed tree cut) and $F n F$ is the boundary length between final-felled and not final-felled simulation units.

The sub-utility functions for $N P V, C C$ and $F F$ were linear so that the minimum possible value of the variable gave a zero sub-utility while the maximum possible value gave sub-utility equal to one. $C n C$ and $F n F$ were minimized and therefore the lowest possible value resulted in sub-utility one and the largest value in sub-utility zero. The sub-utility function for $H V$ was ascending-descending so that sub-utility increased until the target harvest $\left(35,000 \mathrm{~m}^{3}\right.$ for the 900 -ha area and $140,000 \mathrm{~m}^{3}$ for the whole 3600-ha area) after which it decreased until it was zero at the maximum possible harvest.

In the non-spatial problem, the weights of both objective variables were equal. The weights of all six objective variables were also equal in the spatial problems when large segments were used as simulation units. Since it was assumed that there is a greater need for aggregation with smaller simulation units, weights $w_{3}-w_{6}$ were 1.5 times larger than $w_{1}$ and $w_{2}$ when working with small segments, and twice are large as $w_{1}$ and $w_{2}$ when working with cells.

\section{Results}

\section{Segmentation}

When aiming at "small" segments, the average area of the segments was 0.36 ha in the whole area (3600 ha) and 0.35 ha in the sub-area of 900 ha (Fig. 2). The area of the smallest segment was 0.03 ha (exactly: $256 \mathrm{~m}^{2}$, i.e., the area of one cell) in both cases while the largest segment was 8.01 (sub-area) or 14.90 ha (whole area). When the aim was to create "large" segments, their average area was 1.27 ha (whole area) or 1.14 ha (sub-area) with a range of 0.03-8.96 ha (sub-area) or 0.03-11.85 ha (whole area).

Segmentation explained $54.6-98.1 \%$ of the total variation in site and growing stock attributes between grid cells (Table 1). The degree of explained variance $\left(R^{2}\right)$ was the highest for soil group (mineral soil, spruce mire, pine bog, open bog) and the lowest for stand basal area. Logically, $R^{2}$ was higher for small segments than for large segments. 


\section{Initial inventory}

When segments were used to calculate the totals of growing stock variables, saw log volume was underestimated by $1-2 \%$ and pulpwood volume was overestimated by $3-6 \%$, as compared to results derived from grid cells (Table 2). The total growing stock volume was overestimated by $1 \%$, and the species-specific total volumes were overestimated by $1-2 \%$. The largest bias was observed in volume increment where the overestimate was $5 \%$ for small segments and $9 \%$ for large segments.

As expected, the area of the most common fertility class (herb-rich) was overestimated when segments were used to calculate the areas of fertility classes (Fig. 3). The overestimate was $2 \%$ for small segments and $9 \%$ for large segments. The areas of the "adjacent" fertility classes (mesotrophic herb-rich and sub-xeric) were underestimated by $6-51 \%$. The largest relative underestimate was obtained for mesotrophic herb-rich site when using large segments. The area estimate of this site class was 147.5 ha when calculated from cells but only 72.6 ha when calculated from large segments.

\section{Treatment prescriptions}

Differences between plans in the areas of different cutting types were not systematic. When segments were used in planning, the volume of harvested pulpwood was 9-23\% smaller and the volume of saw log was $2-11 \%$ larger, as compared to planning where grid cells were used as simulation units (Table 3). The total area of cutting prescriptions was $2-25 \%$ larger in segment-based planning. Since the total harvest was almost the same in all plans, the harvested volume per hectare was larger (3-21\% larger) in cell-based planning.

The spatial layout of cutting prescriptions was very scattered when the plan was combined using non-spatial optimization and cells were used as simulation units (Fig. 4a). Allowing earlier cuttings of cells by reducing the thinning basal area and clear-felling diameter created some cutting aggregations but many cuttings were still very scattered (Fig. 4b). A clear improvement was achieved when spatial optimization was used in planning (Fig. 5).

Major cuttings were concentrated in the same places in all four cases (cells with two different simulation rules, small segments, and large segments) although their exact boundaries differed. The cutting areas of the two segmentbased plans (Fig. 5c, d) resembled each other, but there were differences in the exact boundaries of clear-felling and thinning areas.

The estimated wood production, calculated from harvested volumes and change in standing growing stock volume, was about 4-9\% higher in segment-based planning. This difference is mainly explained by the overestimated growth prediction for segments. Despite higher predicted wood production for segments, the net present value of the non-spatial plan was 3-4\% higher for cells. In the spatial plans, the NPV was almost exactly the same for cells and segments. Spatial optimization decreased NPV by $3.6 \%$ when cells were used, and less than $0.1 \%$ when segments were used. This means that the cost of aggregating cuttings was clearly higher in cell-based planning.

\section{Time consumption of planning}

Of the various steps of the whole planning process, simulation of treatment alternatives was usually the most time consuming (Tables 4, 5). However, when the planning area was larger ( 3600 ha of which 2500 ha was productive forest) segmentation required more computing time than simulation with segments. Non-spatial optimization was very quick as well as spatial optimization with segments. When grid cells were used as simulation units, spatial optimization and simulation were both very time-
Table 1 Statistics calculated for the segments created from grid cells by cellular automaton

\begin{tabular}{llllll}
\hline Variable & \multicolumn{2}{l}{$R^{2 \mathrm{a}}$} & & RMSE $^{\mathrm{b}}$ & \\
\cline { 2 - 3 } & Small segments & Large segments & & Small segments & Large segments \\
\hline Soil group & 0.981 & 0.924 & 0.003 & 0.009 \\
Fertility class & 0.871 & 0.674 & 0.027 & 0.048 \\
Mean diameter $(\mathrm{cm})$ & 0.814 & 0.692 & & 0.605 & 0.728 \\
Mean height $(\mathrm{m})$ & 0.834 & 0.704 & & 0.441 & 0.570 \\
Stand basal area $\left(\mathrm{m}^{2} \mathrm{ha}^{-1}\right)$ & 0.766 & 0.546 & 0.788 & 1.002 \\
\hline
\end{tabular}

The table shows results for the segmentation of the whole study area (3600 ha). The average area of the segments was 0.36 ha when small segments were targeted and 1.27 ha when large segments were targeted ${ }^{\mathrm{a}} R^{2}=1-\mathrm{SSE} / \mathrm{SST}$ where SSE is the variation not explained by the segmentation (sum of squared deviations from segment mean) and SST is the total deviation (sum of squared deviations from overall mean)

${ }^{\mathrm{b}}$ Standard deviation of the difference between cell value and segment mean 
Table 2 Total volumes and predicted annual volume increments calculated for the productive forest ( $2500 \mathrm{ha})$ of the whole study area (3600 ha)

\begin{tabular}{lrcc}
\hline Variable & \multicolumn{1}{c}{ Cells } & Small segments & Large segments \\
\hline Usable volume $\left(\mathrm{m}^{3}\right)$ & 359,793 & 363,294 & 364,817 \\
Saw log volume $\left(\mathrm{m}^{3}\right)$ & 177,252 & 176,051 & 173,873 \\
Small log volume $\left(\mathrm{m}^{3}\right)$ & 12,315 & 11,600 & 11,893 \\
Pulpwood volume $\left(\mathrm{m}^{3}\right)$ & 170,227 & 175,642 & 179,052 \\
Pine volume $\left(\mathrm{m}^{3}\right)$ & 94,144 & 94,734 & 95,293 \\
Spruce volume $\left(\mathrm{m}^{3}\right)$ & 169,888 & 171,013 & 171,453 \\
Birch volume $\left(\mathrm{m}^{3}\right)$ & 95,760 & 97,546 & 98,071 \\
Volume increment $\left(\mathrm{m}^{3}\right)$ & 16,477 & 17,285 & 17,947 \\
\hline
\end{tabular}

although the total area of the segments was the same (Fig. 6).

\section{Discussion}

The use of raster type of forest data will most probably increase in Finnish forest planning since the results of ALS-based forest inventory, calculated for $16 \mathrm{~m} \times 16 \mathrm{~m}$ grid cells, are now (from year 2018 onwards) freely available for forest planners. The current study provided some results and insights into the use of raster data in forest planning calculations. The most straightforward way would be to use the raster cells directly as calculation and simulation units. This would lead to the most precise treatment prescriptions and it would most probably also maximize the efficiency and economic profitability of forest production (Heinonen et al. 2007). This conclusion can be drawn from previous studies (Heinonen et al. 2007) and the fact that cell-based planning produced equally good or higher net present values than segment-based planning although the estimated volume growth was 4-9\% lower for cells.

The forest management plans developed in this study had only one 10 -year period. Longer planning horizons and a higher number of time-periods would provide longer-

Table 3 Areas of different types of cutting and total harvested volume when the planning was based on grid cells or segments

\begin{tabular}{|c|c|c|c|c|c|c|}
\hline \multirow[t]{2}{*}{ Variable } & \multicolumn{3}{|c|}{ Non-spatial problem } & \multicolumn{3}{|c|}{ Spatial problem } \\
\hline & Cells & Small segments & Large segments & Cells & Small segments & Large segments \\
\hline Clear-felling (ha) & 237.9 & 311.1 & 337.8 & 198.2 & 208.1 & 200.4 \\
\hline Thinning (ha) & 604.1 & 547.6 & 587.1 & 617.3 & 718.0 & 960.5 \\
\hline Other cuttings (ha) & 31.8 & 32.3 & 11.5 & 162.1 & 77.5 & 58.7 \\
\hline Total cut area (ha) & 873.8 & 889.0 & 936.4 & 977.6 & 1003.6 & 1219.6 \\
\hline Saw $\log \left(\mathrm{m}^{3}\right)$ & 89,339 & 91,193 & 91,321 & 79,144 & 89,222 & 87,705 \\
\hline Small $\log \left(\mathrm{m}^{3}\right)$ & 1529 & 1743 & 1722 & 2823 & 1995 & 1823 \\
\hline Pulpwood $\left(\mathrm{m}^{3}\right)$ & 51,321 & 47,057 & 46,958 & 60,222 & 48,780 & 50,465 \\
\hline Total $\left(\mathrm{m}^{3}\right)$ & 142,189 & 139,992 & 140,000 & 142,188 & 139,998 & 139,993 \\
\hline
\end{tabular}




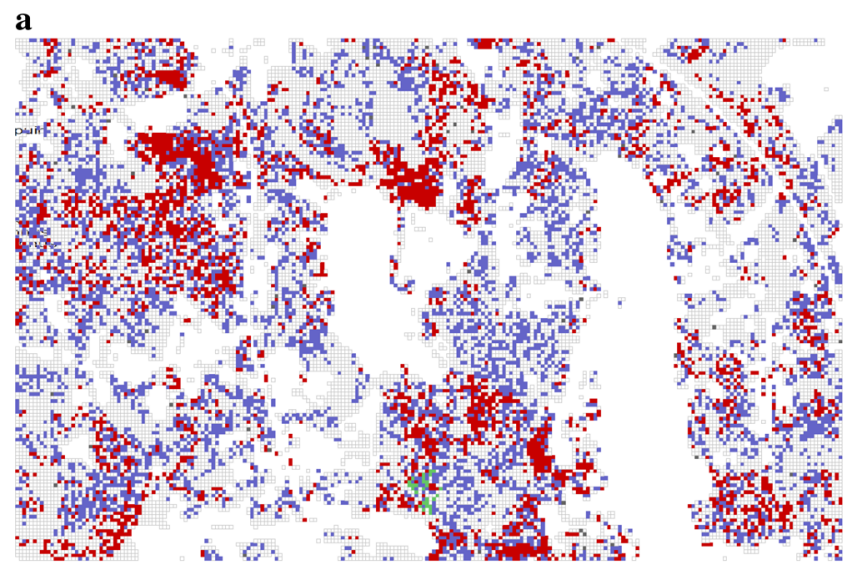

c
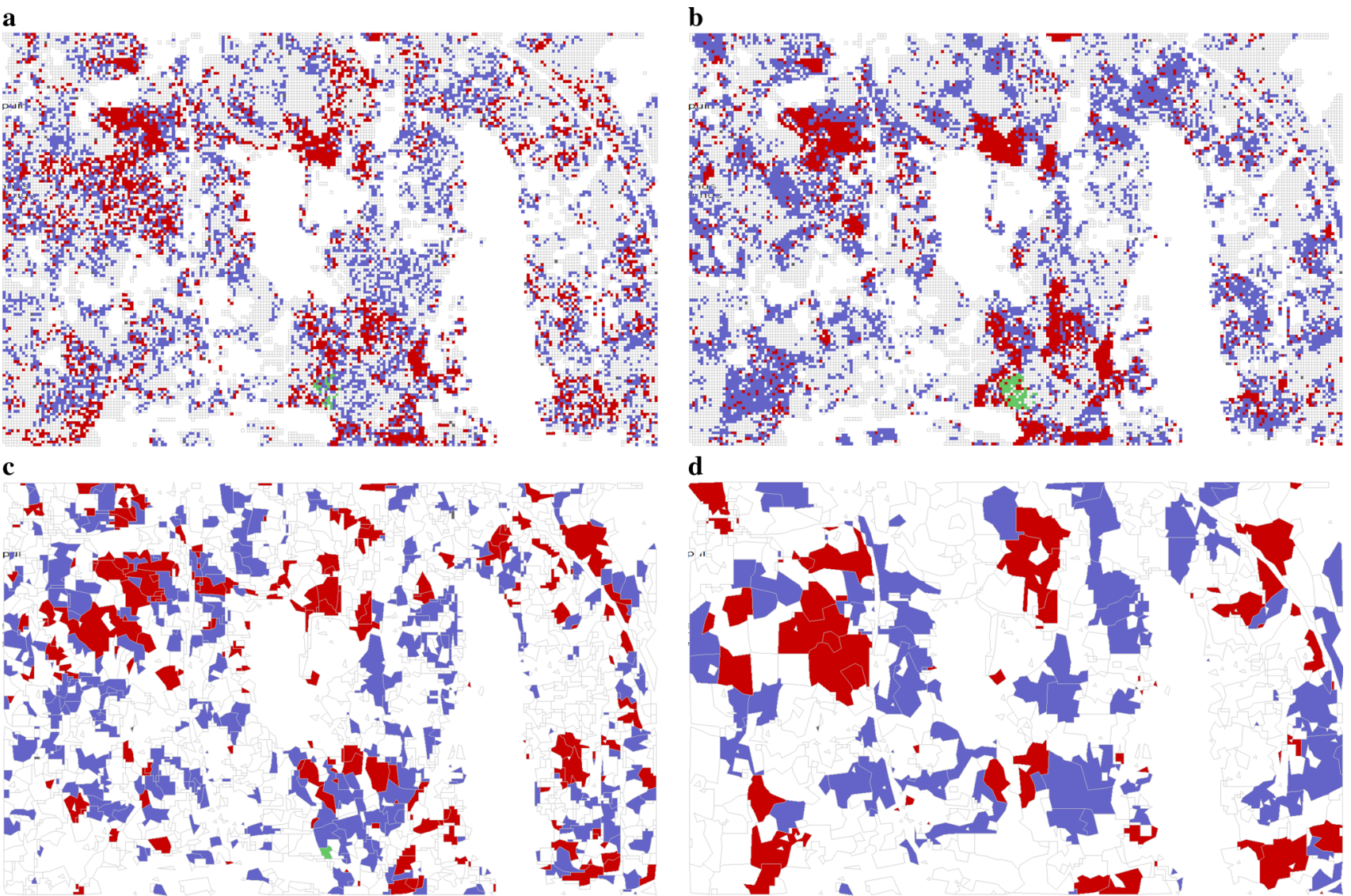

Fig. 4 Cutting areas of the sub-area (900 ha) in non-spatial optimization. Red color is clearcutting, blue color is thinning and green color is seed tree cut (a cells with normal simulation rules; $\mathbf{b}$ cells with premature cuttings allowed; c small segments; $\mathbf{d}$ large segments)

term predictions on the development of the forest resource. It also increases the time consumption of planning calculations, especially in simulation and optimization. It was calculated that in the case of small segments, increasing the number of 10-year periods from one to five increased the simulation time sixfold, due to higher number of alternative treatment schedules and longer duration of the simulation of one schedule. However, the time consumption of spatial optimization increased only twofold.

The use of cells makes it necessary to use spatial optimization in planning, so as to aggregate cuttings and other treatments. On the other hand, segmentation of cells into larger calculation units is not required, which simplifies the planning process. In addition to spatial optimization, it is necessary to allow pre-mature cuttings in some cells within the harvest blocks since otherwise the cutting areas would be scattered and very irregular. The map of Fig. 5b shows that in this case the cutting areas are usually large but they are still clearly more irregular than obtained in segmentbased planning. There are frequently uncut cells within thinning areas and also some thinned cells within clearfelling areas. Uncut cells within thinning blocks are not a problem since these cells are most probably sparse forest where thinning is not required. Thinned cells within clearfelling blocks are places where trees are smaller than in the surroundings. Treating these cells with thinning instead of clear-felling is most probably economically optimal. However, leaving small groups of trees to continue growing in a clear-felling area may increase wind throws.

The results of the study verified the hypothesis that the growth estimate will increase when raster data are organized into larger segments before planning calculations. The reason behind this effect is the concave relationship between stand density and tree growth, and the non-linear relationship between tree size and growth. As a consequence of these relationships, the volume growth of a heterogeneous stand is smaller than that of a homogeneous stand (Pukkala 1990). When segments are used in planning they are assumed to be homogeneous and described with only one set of stand variables. In this study, the effect of segmentation on the growth estimate was substantial: 5\% increase (compared to cells) for small segments ( 0.36 ha in average) and 9\% increase for large segments (average size $1.27 \mathrm{ha}$ ).

The effect of within-stand variation on growth and management has been dealt with in forestry literature 

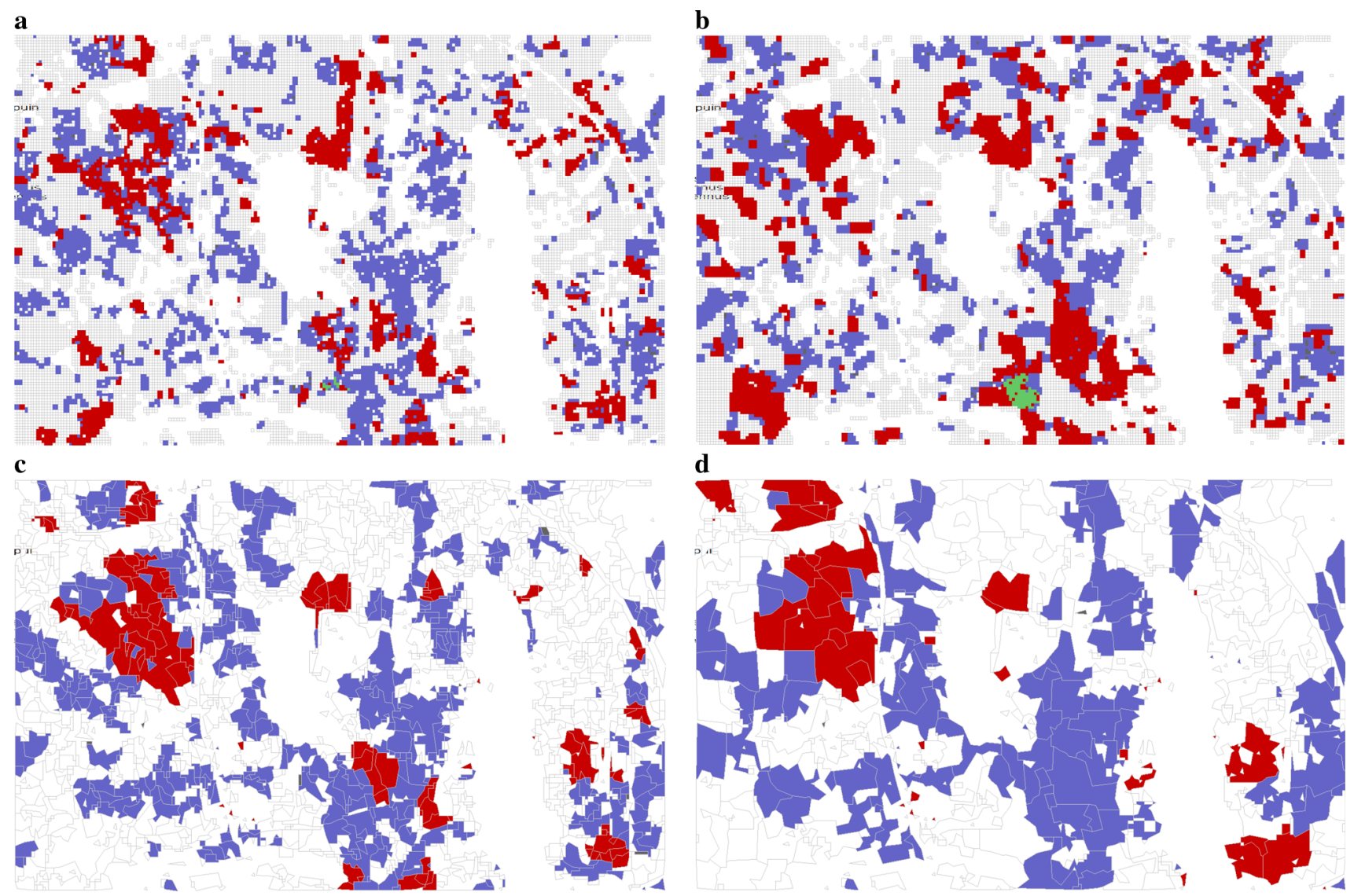

Fig. 5 Cutting areas of the sub-area (900 ha) in spatial optimization. Red color is clearcutting, blue color is thinning and green color is seed tree cut (a cells with normal simulation rules; b cells with premature cuttings allowed; c small segments; d large segments)

Table 4 Time consumption in different steps of the planning process for the larger planning area (900 ha of which 603 ha are productive forest)

\begin{tabular}{llllc}
\hline Operation & Cells, normal simulation rules & Cells, premature cutting allowed & Small segments & Large segments \\
\hline No. of simulation units & 23,562 & 23,562 & 1703 & 530 \\
Segmentation & - & - & $3 \mathrm{~min} 55 \mathrm{~s}$ & $1 \mathrm{~min} 5 \mathrm{~s}$ \\
Simulation & $74 \min 10 \mathrm{~s}$ & $77 \min 40 \mathrm{~s}$ & $5 \mathrm{~min} 40 \mathrm{~s}$ & $2 \mathrm{~min} 4 \mathrm{~s}$ \\
Non-spatial optimization & $1 \min 33 \mathrm{~s}$ & $1 \min 55 \mathrm{~s}$ & $5 \mathrm{~s}$ & $1 \mathrm{~s}$ \\
Spatial optimization & $12 \min 28 \mathrm{~s}$ & $17 \min 1 \mathrm{~s}$ & $53 \mathrm{~s}$ & $14 \mathrm{~s}$ \\
\hline
\end{tabular}

Processor of the computer: Intel(R) Core(TM) i7-4790 CPU @ 3.60 GHz; RAM 16 GB

${ }^{\mathrm{a}}$ The basal area required for thinning and mean tree diameter required for final felling multiplied by 0.8

already long time ago. For example, Pukkala (1990) noted that growth predictions may be smaller when they are based on the individual relascope plots measured in visual compartment inventory, compared to a case where the field data are condensed into a single set of growing stock variables, which is the usual practice in visual compartment inventory. The thinning removal may be larger if thinning is simulated separately for individual field plots. Pukkala and Miina (2005) calculated that the optimal basal area to conduct a thinning treatment is lower in a heterogeneous stand. Also the optimal remaining basal area may be lower for a heterogeneous stand.
A possible way to reduce biases caused by condensing cell-level information into segment-level information is to describe each segment with several sets of stand attributes, based on the variation and correlation of growing stock variables within the segments (Pukkala and Miina 2005). Another possibility is to calculate indices for within-segment variation and use them to correct growth predictions, thinning basal areas, etc. (Corona et al. 2012). A third approach would be to use very small segments, paying much attention to obtaining segments that have low withinsegment variation in stand basal area and average tree size. 
Table 5 Time consumption in different steps of the planning process for the larger planning area (3600 ha of which 2500 ha are productive forest)

\begin{tabular}{llll}
\hline Operation & Cells $^{\mathrm{a}}$ & Small segments & Large segments \\
\hline Number of simulation units & 97,893 & 6885 & 1968 \\
Segmentation & - & $52 \min 50 \mathrm{~s}$ & $20 \min 25 \mathrm{~s}$ \\
Simulation & $320 \min 10 \mathrm{~s}$ & $13 \min 3 \mathrm{~s}$ & $6 \min 42 \mathrm{~s}$ \\
Non-spatial optimization & $26 \min 56 \mathrm{~s}$ & $50 \mathrm{~s}$ & $5 \mathrm{~s}$ \\
Spatial optimization & $113 \min 23 \mathrm{~s}$ & $3 \min 36 \mathrm{~s}$ & $44 \mathrm{~s}$ \\
\hline
\end{tabular}

Processor of the computer: Intel(R) Core(TM) i7-4790 CPU @ 3.60 GHz; RAM 16 GB

${ }^{\mathrm{a}}$ The basal area required for thinning and mean tree diameter required for final felling multiplied by 0.8 (corresponds to "premature cutting allowed" in Table 4)
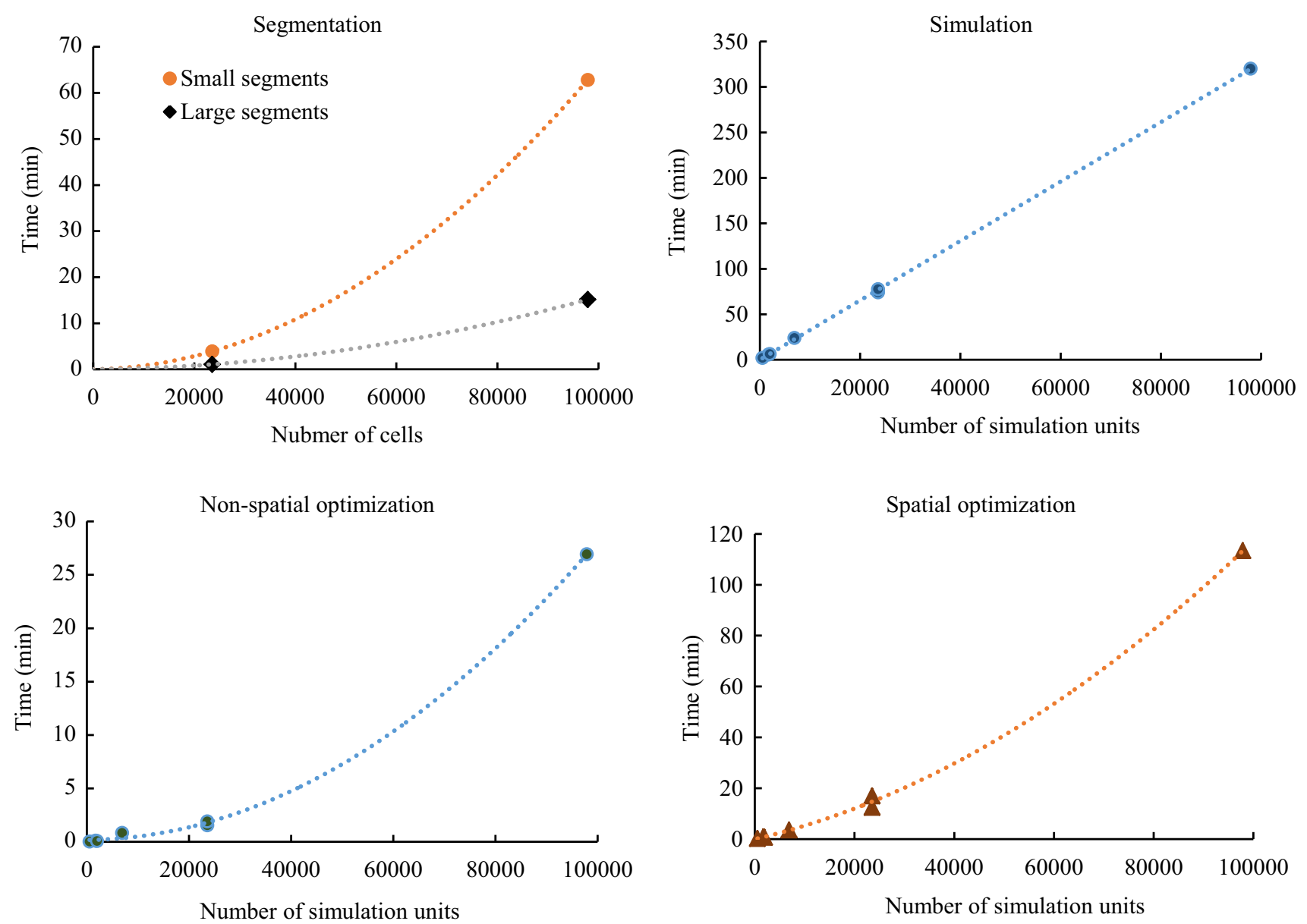

Fig. 6 Time consumption of segmentation, simulation and optimization as a function of the number of grid cells (segmentation) or simulation units (simulation and optimization)

Another anticipated consequence of segmentation was that the areas of the most common site categories were overestimated. Consequently, the areas of more extreme site types (very fertile, very poor) might be clearly underestimated, especially if these sites occur as small spots within continuous areas of more common site types. This type of bias may not be serious for growth prediction and timber management planning, but for instance for ecological planning it would be important to avoid clearly biased estimates of rare sites.
The best method for avoiding the above-mentioned biases would be to use cells as calculation and simulation units in all steps of the planning process. However, this would greatly increase the time consumption of planning. The computing time of the various steps depends on many things, for instance computer, length of the planning period, complexity of the planning problem, optimization method, and the implementation of the procedures (segmentation, simulation, and optimization) as computer programs. Based on the experiences of the current study it can be concluded 


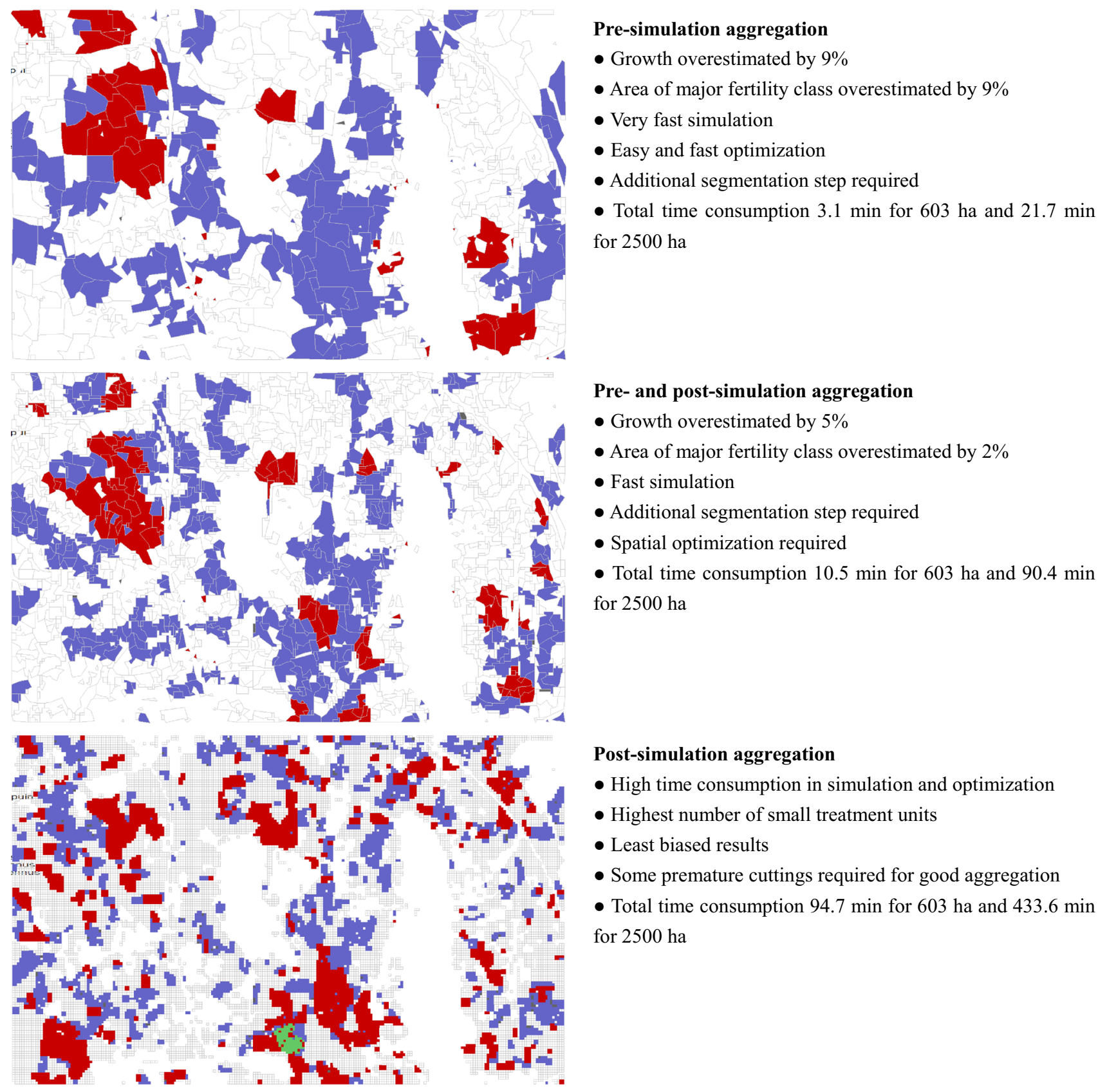

Fig. 7 Summary of the results for different approaches to deal with raster data in forest planning

that the total time consumption is 10-20 times higher in cellbased planning if the number of cells is about 100,000.

The three basic alternatives to deal with small-grained lattice data in forest planning (pre-simulation, pre- and post-simulation, and post-simulation aggregation) are summarized in Fig. 7 for the sub-area of 900 ha. Presimulation aggregation refers to large segments without the use of spatial optimization in planning. It is the easiest approach since spatial optimization is not needed. It is also by far the fastest approach and results in good aggregation of treatments.
The other extreme is to use cells throughout the planning process. It makes the use of spatial optimization necessary, and some of the treatment blocks may be too small for the practical implementation of the plan. The treatment blocks often have irregular shapes. On the other hand, post-simulation aggregation results in the least-biased estimates of site and growing stock variables and the most accurate prediction of removals and future development of the forest. It leads to the most efficient management of the forest resource.

A good compromise between the use of cells and large segments that correspond to normal stand compartments 
would be to use small and homogeneous segments. This would greatly reduce computing time, as compared to using cells as simulation units. The optimal average size of segments might be smaller than the 0.36 ha ( 14 cells) of this study because 0.36 -ha average size still led to biased growth predictions and biased areas of fertility classes. The use of small segments would also lead to the need for spatial optimization to aggregate treatments. In addition to treatments, also other forest features such as old forest habitats could be simultaneously aggregated (Pukkala et al. 2014). Use of small segments leads to computing times that are approximately $10 \%$ of the time consumption of cellbased planning.

Acknowledgments Open access funding provided by University of Eastern Finland (UEF) including Kuopio University Hospital.

Open Access This article is distributed under the terms of the Creative Commons Attribution 4.0 International License (http://crea tivecommons.org/licenses/by/4.0/), which permits unrestricted use, distribution, and reproduction in any medium, provided you give appropriate credit to the original author(s) and the source, provide a link to the Creative Commons license, and indicate if changes were made.

\section{References}

Äijälä O, Koistinen A, Sved J, Vanhatalo K, Väisänen P (2014) Metsänhoidon suositukset. Metsätalouden kehittämiskeskus Tapion julkaisuja. TAPIO

Bettinger P, Graetz D, Boston K, Sessions J, Chung W (2002) Eight heuristic planning techniques applied to three increasingly difficult wildlife planning problems. Silva Fenn 36(2):561-584

Borges JG, Hoganson HM, Falcao A (2002) Heuristics in multiobjective forest management. In: Pukkala T (ed) Multi-objective forest planning. Managing forest ecosystems, vol 6. Kluwer Academic Publishers, Dordrecht, pp 119-151

Corona P, Cartisano R, Salvati R, Chirici G, Floris A, Di Martino P, Marchetti M, Scrinzi G, Clementel F, Travaglini D, Torresan C (2012) Airborne Laser Scanning to support forest resource management under alpine, temperate and Mediterranean environments in Italy. Eur J Remote Sens 45(1):27-37. https://doi. org/10.5721/EuJRS20124503

Dechesne C, Mallet C, Le Bris A, Gouet-Brunet V (2017) Semantic segmentation of forest stands of pure species combining airborne lidar data and very high resolution multispectral imagery. ISPRS J Photogramm Remote Sens 126:129-145

Falcão A, Borges J (2002) Combining random and systematic search heuristic procedure for solving spatially constrained forest management scheduling problems. For Sci 48:608-621

Heinonen T, Kurttila M, Pukkala T (2007) Possibilities to aggregate raster cells through spatial optimization in forest planning. Silva Fenn 41(1):89-103

Heinonen T, Mäkinen A, Rasinmäki J, Pukkala T (2018) Aggregating micro segments into harvest blocks by using spatial optimization and proximity objectives. Can J For Res. https://doi.org/10.1139/ cjfr-2018-0053

Hirvelä H, Härkönen K, Lempinen R, Salminen O (2017) MELA2016: reference manual. Natural Resources and bioeconomy studies 7/2017
Kangas J, Pukkala T (1992) A decision theoretic approach to goal programming problem formulation: an example on integrated forest management. Silva Fenn 26(3):169-176

Lappi J, Lempinen R (2014) A linear programming algorithm and software for forest-level planning problems including factories. Scand J For Res 29(Supplement 1):178-184

Mäkisara K, Katila M, Peräsaari J, Tomppo E (2016) The multisource national forest inventory of Finland. Methods and results 2013. Natural Resources Institute Finland, Natural resources and bioeconomy studies 10/2016, pp 1-215. ISBN 978-952-326-1860. http://urn.fi/URN:ISBN:978-952-326-186-0. Accessed 21 Jan 2019

Maltamo M, Næsset E, Vauhkonen J (eds) (2014) Forestry applications of airborne laser scanning. In: Managing forest ecosystems, vol 27. Springer, Dordrecht, 464 pp. ISBN 978-94-017-8663-7

Mozgeris G (2009) The continuous field view of representing forest geographically: from cartographic representation towards improved management planning. Surv Perspect Integr Environ Soc 2(2):1-8

Næsset E (2002) Predicting forest stand characteristics with airborne scanning laser using a practical two-stage procedure and field data. Remote Sens Environ 80:88-99. https://doi.org/10.1016/ S0034-4257(01)00290-5

Packalén P (2009) Using airborne laser scanning data and digital aerial phographs to estimate growing stock by tree species. Dissertationes Forestales, vol 77. ISBN 978-951-651-242-9

Pascual A, Pukkala T, de Miguel S, Pesonen A, Packalén P (2018) Influence of size and shape of forest inventory units on the layout of harvest blocks in numerical forest planning. Eur J For Res. https://doi.org/10.1007/s10342-018-1157-5

Pukkala T (1990) A method for incorporating the within-stand variation into forest management planning. Scand J For Res 5:263-275

Pukkala T (2004) Dealing with ecological objectives in the Monsu planning system. Silva Lusit Especial:1-15

Pukkala T (2015) Plenterwald, Dauerwald, or clearcut? For Pol Econ 62:125-134

Pukkala T (2019) Optimized cellular automaton for stand delineation. J For Res 30(1):107-119

Pukkala T, Heinonen T (2006) Optimizing heuristic search in forest planning. Nonlinear Anal Real World Appl 7:1284-1297

Pukkala T, Kangas J (1993) A heuristic optimization method for forest planning and decision making. Scand J For Res 8:560-570

Pukkala T, Kurttila M (2005) Examining the performance of six heuristic optimization techniques in different forest planning problems. Silva Fenn 39(1):67-80

Pukkala T, Miina J (2005) Optimising the management of a heterogeneous stand. Silva Fenn 39(4):525-538

Pukkala T, Packalén P, Heinonen T (2014) Dynamic treatment units in forest management planning. Manag For Ecosyst 33:373-392

Shan Y, Bettinger P, Cieszewski CJ, Li TR (2009) Trends in spatial forest planning. Math Comput For Nat Resour Sci 1(2):86-112

Tomppo E, Haakana M, Katila M, Peräsaari J (eds) (2008) Multisource national forest inventory. In: Managing forest ecosystems, vol 18. Springer, Dordrecht, 373 pp. ISBN 978-1-40208712-7

Vauhkonen J, Maltamo M, McRoberts RE, Næsset E (2014) Introduction to forestry applications of airborne laser scanning. In: Maltamo $\mathrm{M}$ et al (eds) Forestry applications of airborne laser scanning: concepts and case studies Managing forest ecosystems, vol 27. Springer, Dordrecht, pp 1-16. https://doi.org/10.1007/ 978-94-017-8663-8_1

Publisher's Note Springer Nature remains neutral with regard to jurisdictional claims in published maps and institutional affiliations. 